\title{
How Much Did Excess Debt Contribute to the 1997 Currency Crisis in Korea?
}

\author{
Duo Qin \\ Queen Mary and Westfield College \\ University of London
}

July $1999^{1}$

${ }^{1}$ This paper was first drafted in October 1998. Address: Mile End Road, London E1 4NS, UK; Email: d.qin@qmw.ac.uk 


\begin{abstract}
It is widely believed that seriously excess debt problems form a major cause of the 1997 Asian financial crisis. This paper investigates empirically the role of the debt problems with respect to both the won $/ \$$ US rate fluctuations and the won collapse in November 1997. The problems are represented by two institutional variables in nonlinear equilibrium-correction models. The variables are found to exert positive feedback effects on the won rate returns in three forms: disequilibrium in levels, short-run shocks and explosive bubbles. However, the estimated effects are not so singly conspicuous as to serve as the predictor of a likely crash in the won rate in late 1997. Excess debt is hence found to only constitute one of the many factors which brought about the 1997 won collapse.
\end{abstract}

JEL classification: D50, E22, E44, F31, F34, F41, G20, O16, O23, O53

Key words: disequilibrium, currency crisis, excess debt, institutional variable, self-fulfilling effect, intrinsic bubble, soft-budget constraint 


\section{Introduction}

The 1997 East Asian financial crisis has led to rapidly mounting studies in currency volatilities and crises. ${ }^{1}$ While theorists wrestle with feasible explanations for sudden currency crashes, empirical modellers delve extensively into data for possible crisis predictions. There are, however, still relatively few empirical works which try to verify or test certain theoretical explanations using country-specific data information.

This paper presents such an attempt. It examines how much, from timeseries data, we can identify and estimate the contribution of Korea's excess debt problems to the won crisis in November, 1997. The choice of the subject stems from several considerations. Korea has long been recognised as a model of state-directed, export-led economy which has sustained rapid and continuous growth, and it is the strongest of the Asian economies which suffered currency crises during the 1997 financial turmoil. In fact, the macroeconomic management in Korea was considered generally sound by the international community and the country obtained its OECD membership shortly before the won collapsed. Indeed, there was little forewarning that the Korean currency would not be able to ride out the Asian financial crisis.

The won has been under close control by the Korean government until recent years. This is best seen from the macroeconometric models built by the Bank of Korea, e.g. (BOK, 1993), in which the exchange rate variable is assumed exogenous. The government exchange rate intervention management has nevertheless undergone several phases of liberalization. Prior to

\footnotetext{
${ }^{1}$ There are several web sites which are devoted to the issue of the Asian currency crisis. For example, see "Chronology of the Asian Currency Crisis" at the web address: http://www.stern.nyu.edu/nroubini/asia/. For survey papers, see (Griffith-Jones and Pfaffenzeller 1998), (Kaminsky et al 1998) and (Komulainen 1999).
} 
1980, the Korean won had been pegged to the US dollars. During the 1980s, the won was fixed according to a certain weighted average formula centered around the US dollars, see (Haggard et al 1994; Chapter. 9). In 1993, the government launched a five-year programme of financial liberalisation, in which the exchange rate was to float gradually via widening margins of its fixed fluctuation zones, see for example, OECD surveys (1994; 1996). Unfortunately, the programme was soon affected adversely by the slowdown of the economy since the late 1995 and brought eventually to a disastrous currency collapse in November 1997 (see figure 1), in the wake of financial turmoils in Malaysia, the Philippines, Thailand and Indonesia.

It has been widely recognised that a series of bankruptcies of chaebols, i.e. large Korean conglomerates, in early 1997 seriously damaged foreign investors' confidence in the Korean economy and eventually exposed the won to severe speculative attacks in October 1997 (see footnote 1 for a chronology of the won crash). It is widely known that the bankruptcies were mainly caused by hefty debts due to cumulation of seriously under-performing investment projects, which had been undertaken under weak banking supervision and strong state-directed development policies. The link between currency crises and cumulative debt-ridden investment projects thus serves as key evidence for a number of recent theories and diagnoses. For example, Stiglitz (1998) maintains that deregulated capital accounts combined with under-regulated domestic financial sector is a key weak point of the 1997 Asian financial crisis because it makes the national financial system very vulnerable to external shocks for an open economy, especially shocks from international capital markets, see also (Radelet and Sachs 1998). The under-deregulation is further related to moral-hazard investment behaviour, e.g. see (Krugman 1998), and linked with the soft-budget syndrome which is believed to generate deteri- 
orating economic fundamentals for transitional economies, see (Huang and $\mathrm{Xu}$ 1998). These diagnoses suggest that the recent crisis was not entirely an unforeseeable burst of an explosive bubble fostered by widespread financial panic over external shocks, and that there are certain internal factors with disequilibrium potentials, which have contributed positively to the crisis.

Several recent empirical studies have actually made use of the diagnoses. For instance, Kaminsky et al (1997) use banking crisis, money to reserve ratio, domestic credit to GDP ratio and other ratios as possible leading indicators of currency crises. Kumar et al (1998) choose external debt-export ratio, budget deficit-GDP ratio etc. as explanatory variables in modelling currency crises. Similar variables are also employed by Esquivel and Larraín (1998) and Glick and Rose (1998). However, most of these studies focus on the predictability of currency crises conditioned upon these explanatory variables by means of binary choice models, such as probit or logit models. ${ }^{2}$ What remain largely untackled empirically are questions such as whether such disequilibrium factors have been propagating into currency movements regularly, and how different institutional mechanisms in different emerging markets exert their roles in destabilizing the currency market.

To seek answers to these questions, detailed country-specific econometric models of exchange rate determination are required. The next section reports such an experiment on the Korean won. The modelled effects of excess debt are discussed in Section 3. The main implications of the experiment are

\footnotetext{
${ }^{2}$ Here, binary choice models suffer from a major drawback in that they throw out most of the raw data information on volatilities of currency returns by rigidly catogorising the returns into a zero-and-one (i.e. no-crises versus crises) series. Since crises are very rare in one economy within a certain time period, such models have to rely on merging data from different countries over different time periods, thus losing the capacity of tracing country-specific characteristics.
} 
summarised in the concluding section.

\section{Modelling the Impact of Excess Debt}

In a way, we can view both the first-generation and the second-generation models of currency crises as models which try to explain the crises as resulting from agents' over-reaction to disequilibrium shocks. Here, we choose the equilibrium-correction model (ECM) framework because it enables us to explain empirically the dynamic movement of modelled variables by long-run disequilibrium shocks, short-run exogenous shocks, and random innovative shocks respectively, see (Hendry, 1995) and (Qin and Gilbert, 1997).

We start by adopting the standard theory of exchange rate determination as the model base, namely that the expected nominal exchange rates, $E[R \mid \mathcal{I}]$, for a given information set, $\mathcal{I}$, is determined in the long run by the real exchange rates, defined in terms of the purchasing power parity (PPP) i.e. $R \frac{P_{f}}{P_{h}}$ (the ratio being the foreign price level $P_{f}$ to the domestic price level $P_{h}$ ), and the interest parity, $I d=I_{h}-I_{f}$ (i.e. the difference between the domestic and foreign interest rates). Specifically, we assume the following functional form:

$$
\begin{array}{rlrl}
E\left[R_{t} \mid \mathcal{I}\right] & =R_{t}\left(\frac{P_{f}}{P_{h}}\right)_{t} \exp \left\{\delta I d_{t-1}\right\}, & 0<\delta<<1 \\
E\left[r_{t} \mid \mathcal{I}\right] & =r_{t}-\ln \left(\frac{P_{f}}{P_{h}}\right)_{t}+\delta I d_{t-1}, \quad r=\ln R
\end{array}
$$

Notice that the above theoretical model implies the long-run disequilibrium

shocks being $\left\{\ln \left(\frac{P_{h}}{P_{f}}\right)_{t}-\delta I d_{t-1}\right\}$, and that, for very small $\delta, R \gtrsim R \frac{P_{f}}{P_{h}}$ when $I_{h}>I_{f}$, i.e. the nominal rates are slightly undervalued with respect to the PPP defined real rates, and vice versa, a phenomenon which seems to fit the won situation depicted in figure 2. Specifically, we see from the top two graphs of figure 2 a more or less continuous and narrow gap between the nom- 
inal and the PPP defined real rates prior to the 1997 crisis, whereas the gap largely disappears when we take the interest parity into consideration (the bottom two graphs; see also figure 3 for the graphs of the interest parities).

Embedding (1) into an ECM of $\Delta r_{t}=\ln \left(R_{t}-R_{t-1}\right)$, i.e. the nominal rate returns, we get:

$$
\begin{aligned}
\Delta r_{t}= & \theta_{0}+\theta_{1}\left[\ln \left(\frac{P_{h}}{P_{f}}\right)_{t-1}-\delta I d_{t-2}\right] \\
& +\alpha(L) \Delta r_{t-1}+\beta(L) \Delta I d_{t-1}+\gamma(L) \Delta \ln \left(\frac{P_{h}}{P_{f}}\right)_{t}+\varepsilon_{t} \\
& \varepsilon_{t \widetilde{\mathrm{c}}} I I D\left(0, \sigma_{\varepsilon}^{2}\right)
\end{aligned}
$$

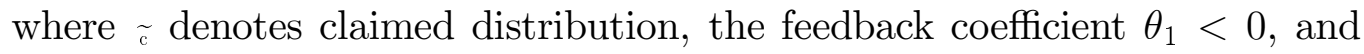
$\alpha(L), \beta(L)$ and $\gamma(L)$ are polynomial in lag operator $L$ of order $k$ such that $\left\{\varepsilon_{t}\right\}$ will not be autocorrelated.

Since ECMs normally suffer very little from colinearity problems, we should be able to augment (2) easily by a set (vector) of country-specific, excess debt variables, $\mathbf{S}^{\prime}=\left(S_{1}, \cdots S_{i}, \cdots S_{q}\right)$, which exacerbate the nominal rate fluctuations in a way that neither interest rates nor inflation differentials would capture. These variables can be regarded as representing disequilibrium shocks due to particular institutional characteristics of the economy under investigation, and have thus been referred to as institutional variables by Qin and Vanags (1996) and Qin (1998). Here, the effects of the excess debt can be specified into three types: disequilibrium level effect, short-run shock effect and intrinsic bubble or self-fulfilling effect, ${ }^{3}$ i.e.:

$$
\varepsilon_{t}=f\left(\mathbf{S}, \Delta \mathbf{S},|\mathbf{S}|^{\boldsymbol{\tau}}\right)_{t-1}+\nu_{t}, \quad \boldsymbol{\tau}>\mathbf{1}, \nu_{t \tau} \operatorname{IID}\left(0, \sigma_{\nu}^{2}\right)
$$

\footnotetext{
${ }^{3}$ The idea of modelling intrinsic bubbles was originally proposed by Froot and Obstfeld (1991) in the context of stock pricing determination.
} 
Taking a log-linear form of (3) and combining it into (2), we get:

$$
\begin{aligned}
\Delta r_{t}= & \theta_{0}+\theta_{1}\left[\ln \left(\frac{P_{h}}{P_{f}}\right)_{t-1}-\delta I d_{t-2}-\sum \varkappa_{i} s_{i, t-2}\right] \\
& +\alpha(L) \Delta r_{t-1}+\beta(L) \Delta I d_{t-1}+\gamma(L) \Delta \ln \left(\frac{P_{h}}{P_{f}}\right)_{t} \\
& +\sum \lambda_{i}(L) \Delta s_{i, t-1}+\sum \rho_{i}\left|s_{i, t-1}\right|^{\iota_{i}}+\nu_{t}, \quad s_{i}=\ln S_{i}
\end{aligned}
$$

Two problems are in need of solution before we attempt to estimate (4). One is concerned with the choice of $\mathbf{S}_{t-1}$ and the other the nonlinearity of (4). It should be noted that the bubble effect may not be the only source of nonlinearity. Another source is the possible ARCH (AutoRegressive Conditional Heteroscedasticity) effect in $\nu_{t}$, i.e.

$$
\sigma_{\nu_{t}}^{2}=\omega_{0}+\sum_{j=1}^{l} \omega_{j} \nu_{t-j}^{2}
$$

an effect observed frequently from empirical models of nominal rate returns, see e.g. (de Vries, 1995). to circumvent the problem, model specification via estimation is carried out here in two sequential steps. First, a simplified (4) without the term $\sum \rho_{i}\left|s_{i, t-1}\right|^{\iota_{i}}$ is estimated by OLS methods to enable us to gradually reduce the model following the general $\rightarrow$ simple dynamic specification approach, see e.g. (Hendry, 1995). Once the reduction has reached a dynamically most parsimonious form, we augment it by both the bubble effect and the ARCH effect, and re-estimate the model by the ML method.

As for the choice of variables representing excess debt, Kaminsky et al (1998) provide a list (Table A2) of leading indicators used by empirical modellers, see also the variables used in (Esquivel and Larraín, 1998) and (Kumar et al, 1998). The variables mostly take the forms of growth rates and ratios, e.g. the credit growth, the ratio of foreign reserve to GDP, the ratio of external debt to total bank loans etc.. They cover broadly two aspects: 
unbalanced debt profile in either domestic or foreign financial markets, e.g. the ratio of investment credit to GDP, and disproportionate loan terms, e.g. the ratio of short-term borrowing to long-term capital liabilities. Huang and Zhang (1997) provide a theoretical explanation of the formation of the capital structure in terms of debt-equity ratio by a general intertemporal equilibrium model. Their model actually offers a feasible rationale for the unbalanced debt profile problem in a closed economy. Specifically, excess debt can be viewed as disequilibrium between the asset-demand (wealth-equity) ratio and the debt-equity ratio, which can then be embodied statistically by the ratio of wealth to debts. ${ }^{4}$ Here, we use M2 as the proxy to wealth and total commercial bank loans as the proxy to debts and designate the variable by $S l .{ }^{5}$ Since that ratio only covers domestic imbalance in the debt profile, we bring in another variable, $S f$, the share of foreign liabilities in the debt composition. As mentioned earlier, indicators based on the balance of payments account have been used frequently in empirical studies for similar purposes. However, there is a major practical drawback in using data from the balance of payments account. Its update publication is usually very slow, especially in comparison with banking data. ${ }^{6}$ As for the aspect of disproportionate

\footnotetext{
${ }^{4}$ Huang and Zhang (1997) show that there is a certain inverse relationship between the debt-equity ratio and the asset-demand (wealth-equity) ratio. It is then easy to see that the ratio between these two ratios should be constant in a steady state. Notice that equity is cancelled out when we take the ratio of these two ratios, yielding us simply a wealthdebt ratio. Therefore, the time-series properties of this ratio should reflect the investment equilibrium/disequilibrium state of the economy in question.

${ }^{5}$ Admittedly, there is the problem of under representation in both indices. M2 does not fully cover the definition of wealth. The total loans of deposit money banks do not cover all the debts either. However, we expect that the ratio of the two indices would alleviate the problem.

${ }^{6}$ Various lagged variables in the form of ratios using both the current account bal-
} 
loan terms, the available data series for short-term capital balance is unfortunately very short. The alternative of using various combinations of the current balance and the capital balance from the balance of payments account has been tried, but turned out to be insignificant during the model specification-estimation procedure.

Figure 4 illustrates the time series of both monthly and quarterly $s f$ $(=\ln S f)$ and its changing rates, as well as quarterly $s l(=\ln S l)$ and its changing rates. ${ }^{7}$ It is observable that there is a sharp rise in the foreign liability-debt ratio since the mid 1990s (figure 4a and 4c), and that its growth rates also shift upwards since the 1990s (figure 4b and 4d) although there is no discernibly drastic increase in the volatilities immediately before the crisis. On the other hand, the wealth-debt ratio exhibits a steady increase since the mid 1980s (figure 4e), implying a gradual improvement of the overall debt situation. It is equally hard to discern any significant abnormal signs from this variable immediately prior to the crisis.

The modelling experiment is carried out using two data sets: one quarterly set covering the period of 1980Q1 to 1998Q2 and the other monthly set covering the period of $1980 \mathrm{M} 1$ to $1998 \mathrm{M} 6) .{ }^{8}$ The end part of the data sets starting from the crisis (1997Q4 or 1997M10) is reserved for forecasting and thus not used in the model specification-estimation process. The main results from the two modelling steps are summarised in tables 1, 2, 3 and 4 . Table 5 reports the unit-root tests of all the variables.

ance/deficit and the capitcal account balance/deficit series have actually been experimented during the model specification-estimation process. None of them has survived the model reduction.

${ }^{7}$ Graphs of monthly $s l$ are omitted because the variable is found insignificant in the monthly models.

${ }^{8}$ The sources and the definitions of the data used here are given in the appendix. 
It is clear from the tables that the part of the model results which correspond to the standard theory (1) is in conformity with many other empirical findings, e.g. small, but significant, interest rate parity effect and the PPP effect, and the weakening of these effects as well as the goodness of fit as the data frequency increases, see e.g. (de Vries, 1995) and (Hallword and MacDonald, 1994). This enables us to focus on the two institutional variables, $s f$ and $s l$. We find that both $s f$ and $s l$ exert significantly leading short-run shock impact on the exchange rate returns in the quarterly model, but that $s l$ drops out in the monthly model whereas lagged $s f$ exhibits both shortrun shock and disequilibrium level effects, and that only $s f$ demonstrated a significant bubble or self-fulfilling effect. Noticeably, both linear models have failed the diagnostic $\mathrm{ARCH}$ test (see tables 1 and 2). ${ }^{9}$ A significant 1st-order ARCH effect is thus captured by the nonlinear models (see tables 3 and 4).

Before examining closely the economic implications of $s f$ and $s l$ from these model results, we need to look at the possible 'collinearity' between these institutional variables and the other explanatory variables. Table 6 reports their correlation coefficients as well as the percentage changes in the partial correlation coefficients of the other explanatory variables with the returns when both $s f$ and $s l$ are dropped out from the models. It is discernible from table 6 that there exist certain degrees of correlation but the correlation is mostly complementary, except for the case of the inflation ratio variables. ${ }^{10}$ However, it is worth noting that the inflation ratio variable and the institutional variables do not appear simultaneously in the models,

\footnotetext{
${ }^{9} \mathrm{It}$ is also found that the order of the $\mathrm{ARCH}$ relation in (5) is $l=1$ from the tests. The actual results are not reported here for simplicity.

${ }^{10}$ When the correlation between two explanatory variables is substitutive rather than complementary, the partial correlation coefficient would decrease substantially if one of the variables is dropped out, see (Hamilton, 1987).
} 
implying that part of the excess debt shocks must have been fed subsequently into the inflation differentials.

\section{How much did Excess Debt Contribute to Won Crisis?}

Let us now concentrate on the question of how much we can identify from the models the contribution of excess debt to the 1997 won crisis. The modelling results have definitely shown that both institutional variables propagate shocks and volatilities into the nominal rate returns. Specifically, tables 1 and 3 show that wealth-debt ratio, sl, exerts a negatively leading, growth-rate effect on $\Delta r_{t}$, with an estimated impact multiplier of the range $(-0.16,-0.12)$. This implies that a sudden increase of debt over a given level of wealth (i.e. a drop in $S l$ ) would generate, ceteris paribus, a subsequent depreciatory pressure on the won rate (i.e. an increase in $R$ ). However, such pressure does not seem to be enormous given the lack of highly abnormal movements of this variable prior to the crisis (see figure $4 \mathrm{e}$ and $4 \mathrm{f}$ ). Nor should it be cumulative unless there exists a nonvanishing growth rate in $S l$ on average. Calculation using the quarterly data set demonstrates that the sample mean of $\Delta_{4}$ sl is insignificant from zero.

In comparison, the variable $S f$, i.e. the foreign liability-debt ratio, is found to have played a much more substantial role. Its modelled impact on the nominal rates take all the three types specified in (3). First of all, it is worth noting that both the levels and the growth rates of this variable exhibit a few phases of mean shifting, as easily seen from figure 4 . For instance, $\Delta_{3} s f_{t}$ (figure 4b) had a mean of $-0.09(\text { s.d. }=0.049)^{11}$ during 1986-90 and a mean of

\footnotetext{
${ }^{11}$ Here, s.d. stands for standard deviation.
} 
$0.05(s . d .=0.04)$ during $1995-97$ prior to the crisis in the monthly set, while $\Delta_{4} s f_{t}$ (figure 4d) had a mean of $-0.324(s . d .=0.01)$ during 1986-90 and a mean of 0.224 (s.d. $=0.06)$ during $1995-97$ prior to the crisis in the quarterly set. Therefore, the positively leading, short-run impact of this variable could cumulate over several years, resulting in a larger positively feedback effect than the impact multiplier, as estimated around 0.08 in the quarterly model (see table 3) and around 0.13 (see table 4) in the monthly model. Moreover, $s f$ is found to exert disequilibrium level effect in the monthly model, a result which seems to correspond to the medium-term mean-shifting feature of the data (see figure $4 \mathrm{a}$ ). To evaluate more precisely the cumulative effect of $s f$ in the models, we plot in figure 5 the lag weights $w_{i}$ of $s f$ based on the ML results of tables 3 and 4 , and the lagged cumulative effect, $\sum w_{i-1} s f_{t-i-1}$, on $r_{t}$ from 1994 to the end of $1997 .{ }^{12}$ The significantly positive leading effects of $s f$ preceding the crisis are strikingly evident from the graphs.

Let us now turn to the intrinsic bubble effect of $s f$. The positive exponential coefficient estimates are remarkably large and significant, i.e. $\tau \approx$ $(5.5,6)$, implying that the foreign currency market has been extremely sensitive to news concerning Korea's foreign liability-debt positions. Moreover, the sensitivity increases proportionately as we move from the quarterly model $\rho_{1}=0.0003$ to the monthly model $\rho_{1}=0.0009$. This is intuitively unsurprising since higher frequency data contain more information than lower frequency data on instant reactions, often overreactions, of agents to unexpected news. However, we cannot perceive any omen of the imminence of a collapse in the nominal returns from the bubble effects plotted in the bot-

\footnotetext{
${ }^{12}$ The lag weights and the cumulative effects are calculated by rewriting the models in tables 3 and 4 into final equations. To facilitate the illustration, the means of the cumulative effects are matched with the means of the nominal rates in the two middle graphs of in figure 5 .
} 
tom two graphs in figure 5. But we must not forget that $\tau$ is not the only self-reinforcing factor in the models. The strong first-order $\mathrm{ARCH}$ effect, i.e. $\omega_{1} \approx(0.42,0.52)$, should be regarded as another factor. ${ }^{13}$

In spite of the reasonably good explanatory power of the institutional variables, the models totally mispredict the 1997 won collapse, as shown in figure 6. Notice, however, that the predictive power of the models has recovered quickly towards the end of the prediction period (i.e. the mid 1998). We could thus infer with a comfortable degree of confidence that excess debt on the whole has only contributed to, rather than triggered, the 1997 won crisis. In other words, the won crisis remains largely unpredictable even conditioned upon the adverse situation in the external capital markets, as reflected by the liability-debt ratio.

Diba and Grossman (1988) propose to use tests for breakdowns in cointegrated relations as the tests for the presence of explosive, rational bubbles, which are assumed to come from a latent martingale process in the form of an extraneous variable with respect to a specified structural model, see also (Cuthbertson, 1996; Chapter 7). In table 5, Dickey-Fuller and augmented Dickey-Fuller tests for unit roots are reported for two different samples, one for the period preceding the crisis and the other for the whole period. Notice from the last row of table 5 that the inclusion of the crisis in the second sample has turned the property of stationarity into that of a unit root for the log price ratio series, i.e. the cointegrated relation between the log nominal and the log real rates (see also the middle two graphs in figure 2), whereas the $I(1)$ properties of the both rates and the $I(0)$ properties of their returns remain unchanged irrespective of the different sample periods. Combining

\footnotetext{
${ }^{13}$ For related issues on ARCH modelling, see e.g. Harvey et al (1992), Sentana (1995), and Hafner (1998).
} 
these unit-root tests with the model results, we can conclude that external spillover and contagion are more likely to have triggered the 1997 won crash, in comparison with the domestic debt problems, see (Masson 1998) and (Glick and Rose 1998).

\section{Concluding Remarks}

The present empirical study renders mainly the following:

1. Excess debt in Korea is found to continuously exert perturbing feedbacks to the won/\$US rates, and thus have contributed significantly to Korea's currency collapse in the late 1997. Excess debt is represented here by two institutional variables: wealth-debt ratio and liability-debt ratio, with the latter variable being the most important one. The effects of the two variables are further specified into three types: disequilibrium level effect, short-run shocks and self-fulfilling explosive bubbles.

2. In spite of the reasonably sound model results, the 1997 won crisis remains virtually unpredictable. This reinforces the common view that the exchange rate policies per se in Korea have been prudent and well in line with the markets by and large.

3. Theoretically, the modelled effects of excess debt can be regarded as being caused by disequilibrium not only in the internal capital structure of the economy, but also in the external debt structure. The effects also fit, in principle, with the theorisation of the soft-budget constraint syndrome by Huang and $\mathrm{Xu}$ (1998). However, the effects estimated in the models are less direct, less dominant and dynamically more complicated than what Huang and $\mathrm{Xu}$ suggest. In particular, the effects are 
found to be mainly explanatory rather than predictive. This finding inclines us to ascribe the main cause of the won crisis to 'spillover' or 'contagion', as theorised by Masson (1998), and to rational, short-term speculative activities in the international currency market, as analyzed by Osler (1998).

4. Practically, the model results carry interesting policy implications. Primarily, great caution should be exercised in the design of any macro policies relating to financial market liberalisation when the currency is in virtually free floatation, irrespective of the existing degrees of exchange-rate controls, since the closer the currency is allowed to take its market values, the more susceptible the exchange rate becomes to a multitude of random shocks and hence the less predictable its volatility. Under such circumstances, it is far from sufficient for policy makers to monitor the band of the nominal return movements narrowly by the movements of the economic fundamentals. What becomes crucially important is to maintain exchange-rate policies well in coordination with any other policy programmes on financial liberalisation. ${ }^{14}$ Financial marketisation has reduced the scope, or increased the risk, of disequilibrium policy maneuvering domestically. Finally, policy makers should pay more attention not only to the possible dynamic complications of short-term shocks to the exchange rate relating to speculative activities in the world currency market, but also to the possible cumulative effect of the past or existing disequilibrium problems in the domestic

\footnotetext{
${ }^{14}$ Take the two institutional variables for example. The debt problems that they embody appear to be no worse for the post 1990 period than the period before 1985 (see figure 4). But the won has become much more sensitive to debt problems for the post 1990 period due to the opening up of the economy to the international capital markets.
} 
economy, once they have decided to unleash the home currency into the world market.

The present modelling exercise is limited to finding empirically the role of the debt problems in the won rate fluctuations. Many issues have been left aside. Further model extensions are definitely desirable, especially in relation to the questions of how the debt problems feed into international capital markets, how the Korean case compares with other open economies with comparably serious debt problems, whether certain safety boundaries of the debt ratios are estimable with respect to the exchange rate fluctuations under different policy scenarios, and how the degrees of institutional disequilibrium effects could be related to the susceptibility of the economy to regional spillover and contagion.

\section{Appendix: Data Sources}

Most of the data series come from Monthly Statistical Bulletin (MSB) published by the Bank of Korea. The Bank also maintains a web-site data bank at http://www.bok.or.kr/kobank/owa/. The rest of the series come from the International Financial Statistics (IFS) Monthly by the IMF.

$R$ : exchange rate of won per U.S. dollar, end of the period, MSB

$I_{h}$ : money market interest rate of Korea, code 60b, IFS

$I_{f}$ : Federal Funds rate of US, 60b, IFS

$P_{h}$ : wholesale price index of Korea $(1990=100)$, code 63 , IFS

$P_{f}$ : wholesale price index of US $(1990=100)$, code 63 , IFS

$S l$ : M2/total loans of deposit money banks of Korea, end of period, in million won, MSB 
$S f$ : foreign liability/total loans of deposit money banks of Korea, end of period, in million won, MSB

\section{References}

[1] BOK (1993) The Macroeconometric Model of the Korean Economy, Institute for Monetary and Economic Research, the Bank of Korea.

[2] Cuthbertson, K. (1996) Quantitative Financial Economics, Chichester: John Wiley \& Sons.

[3] Diba, B. T. and Grossman, H. L. (1988) "Explosive Rational Bubbles in Stock Prices", American Economic Review, 78, 520-30.

[4] Esquivel, G. and Larraín, F. B. (1998) "Explaining Currency Crises", Development Discussion Papers no. 666, Harvard Institute for International Development.

[5] Froot, K. A. and Obstfeld, M. (1991) "Intrinsic Bubbles: the Case of Stock Prices", American Economic Review, 81, 1189-214.

[6] Glick, R. and Rose, A. K. (1998) "Contagion and Trade: Why Are Currency Crises Regional?" (Revised Draft from http://haas.berkeley.edu/ arose).

[7] Griffith-Jones, S. and Pfaffenzeller, S. (1998) "The East Asian Currency Crisis: A Survey of the Debate on its Causes and Possible Solutions", draft for Commonwealth Secretariat Expert Group Meeting, London, June 1998 (at http://www.ids.ac.uk/ids/research/easia.html). 
[8] Hafner, C. M. (1998) "Estimating High-Frequency Foreign Exchange Rate Volatility with Nonparametric ARCH Models", Journal of Statistical Planning and Inference, 68, 247-69.

[9] Hallwood, P. and MacDonald, R. (1994) International Money and Finance, (2nd edition), Oxford: Blackwell.

[10] Hamilton, D. (1987) "Sometimes $R^{2}>r_{y x_{1}}^{2}+r_{y x_{2}}^{2}$ : Correlated Variables Are Not Always Redundant", The American Statistician, 41, 129-32.

[11] Harvey, A., Ruiz, E. and Sentana, E. (1992) "Unobserved Component Time-Series Models with ARCH Disturbances", Journal of Econometrics, 52, 129-57.

[12] Hendry, D. F. (1995) Dynamic Econometrics, Oxford: Oxford University Press.

[13] Haggard, S., Cooper, R. N., Collins, S., Kim, C. and Ro, S.-T. (1991) Macroeconomic Policy and Adjustment in Korea, 1970-1990, Harvard Institute for International Development and Korea Development Institute, Harvard University Press.

[14] Hansen, B. E. (1992) "Testing for Parameter Instability in Linear Models", Journal of Policy Modelling, 14, 517-33.

[15] Huang, H.-Z. and Xu, C.-G. (1999) "Financial Institutions and the Financial Crisis in East Asia", London School of Economics working paper at http://econ.lse.ac.uk/staff/cxu/papers/Fincris8.pdf, forthcoming in European Economic Review.

[16] Huang, H.-Z. and Zhang, J.-X. (1997) "A General Intertemporal Equilibrium Model of Capital Structure and Portfolio Selection", draft. 
[17] Kaminsky, G., Lizondo, S. and Reinhart, C. M. (1998) "Leading Indicators of Currency Crises", IMF Staff Papers, 45, 1-48, International Monetary Fund.

[18] Kumar, M., Moorthy, U. and Perraudin, W. (1998) "Predicting Emerging Market Currency Crashes", the Institute for Financial Research Working Papers 51, Birkbeck College, University of London.

[19] Komulainen, T. (1999) "Currency Crisis Theories - Some Explanations for the Russian Case", BOFIT Discussion Papers no 1, Institute for Economies in Transition, Bank of Finland.

[20] Krugman, Paul (1998) "What Happened to Asia?" mimeo, MIT, 1998.

[21] Masson, P. (1998) "Contagion: Monsoonal Effects, Spillovers, and Jumps between Multiple Equilibria", IMF Working Papers 142, International Monetary Fund.

[22] OECD (1994), OECD Economic Surveys: Korea, OECD.

[23] OECD (1996), OECD Economic Surveys: Korea, OECD.

[24] Osler, C. L. (1998) "Short-term Speculators and the Puzzling Behaviour of Exchange Rates", Journal of International Economics, 45, 37-57.

[25] Qin, D. (1998) "Disequilibrium Institutional Factors in Aggregate Money Demand: Evidence from Three Economies", Journal of Development Economics, 57, 457-71.

[26] Qin, D. and Gilbert, C. L. (1997) "The Error Term in the History of Time Series Econometrics", Economics Department Discussion Papers, 369, Queen Mary and Westfield College, University of London. 
[27] Qin, D. and Vanags, A. (1996) "Modelling the Inflation Process in Transition Economies: Empirical Comparison of Poland, Hungary and Czech Republic", Economics of Planning, 29, 147-68.

[28] Radelet, S. and Sachs, J. (1998) "The East Asian Financial Crisis: Diagnosis, Remedies, Prospects," mimeo, Harvard Institute for International Development, 1998.

[29] Sentana, E. (1995) "Quadratic ARCH models", Review of Economic Studies, 62, 639-61.

[30] Stiglitz, J. (1998) "Bad Private-Sector Decisions," Wall Street Journal, February 4.

[31] de Vries, C. G. (1995) "Stylized Facts of Nominal Exchange Rate Returns," in Grossman, G. M. and Rogoff, K. (eds.) Handbook of International Economics, pp. 348-89, Amsterdam: North-Holland. 
Figure 1. Won/US\$ Rates and Their Returns
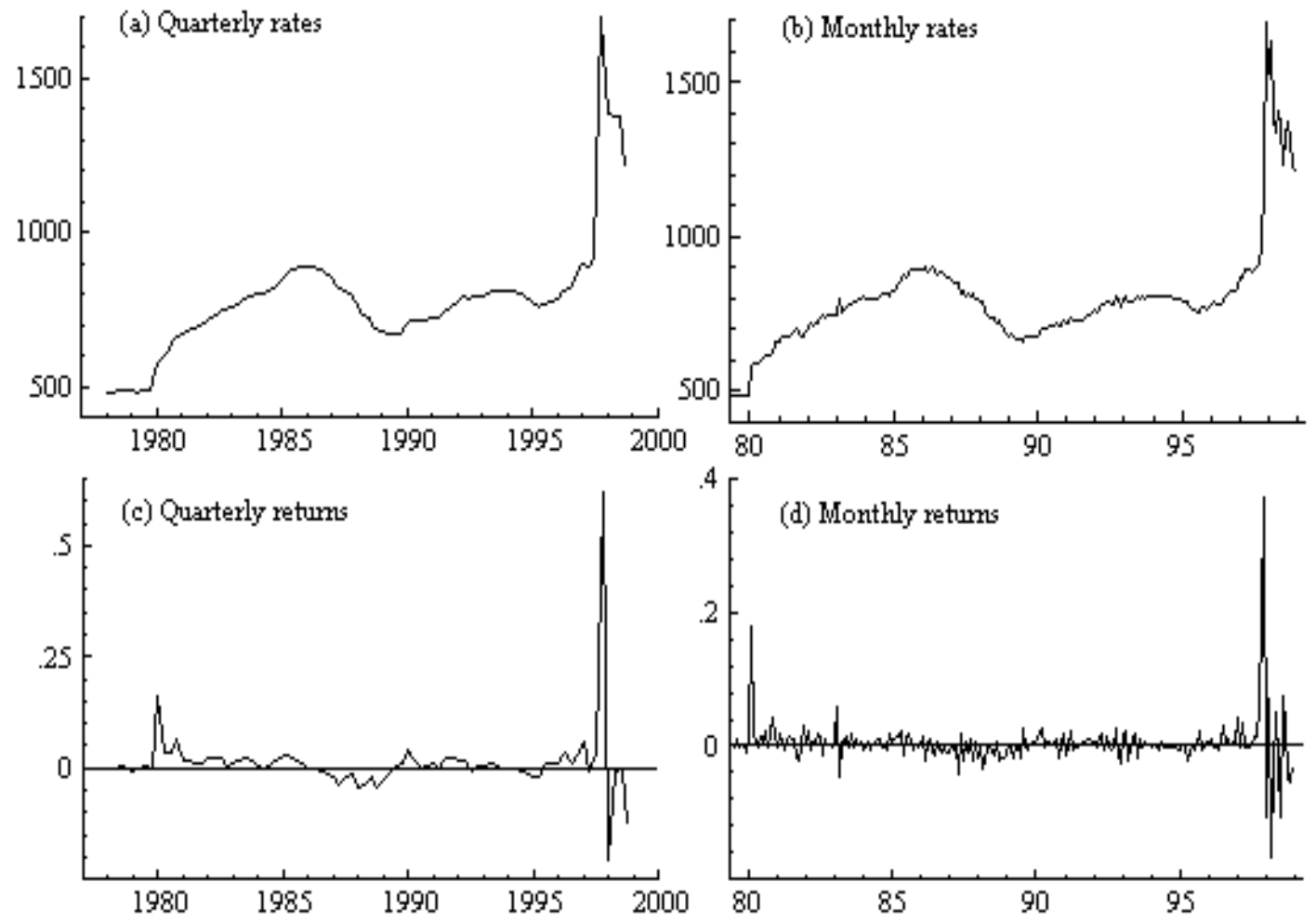
Figure 2. Nominal versus Real Rates and Their Ratios
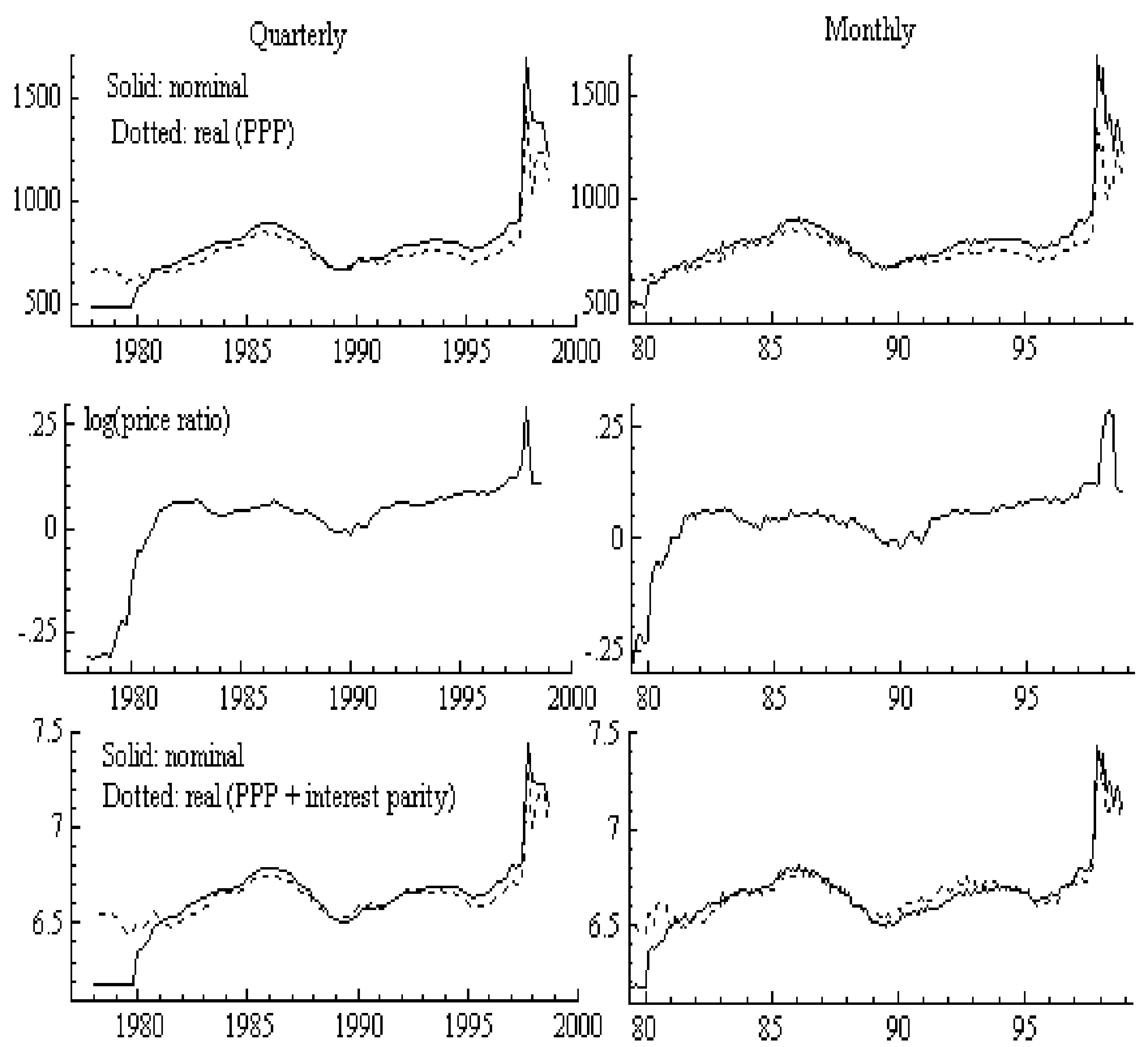

\footnotetext{
${ }^{14}$ In figure 2 , the real (PPP) is calculated by $R \frac{P_{f}}{P_{h}}$, and the real (PPP + interest parity) is calculated by the log form in model (1), where the values of $\delta$ come from tables 1 and 2. Notice that the middle and bottom graphs are in logs, and that the log(price ratio) amounts to the log nominal rates minus the log real rates.
} 
Figure 3. Interest Parity Idand Inflation Differentials $\Delta \ln \left(\frac{P_{h}}{P_{f}}\right)$

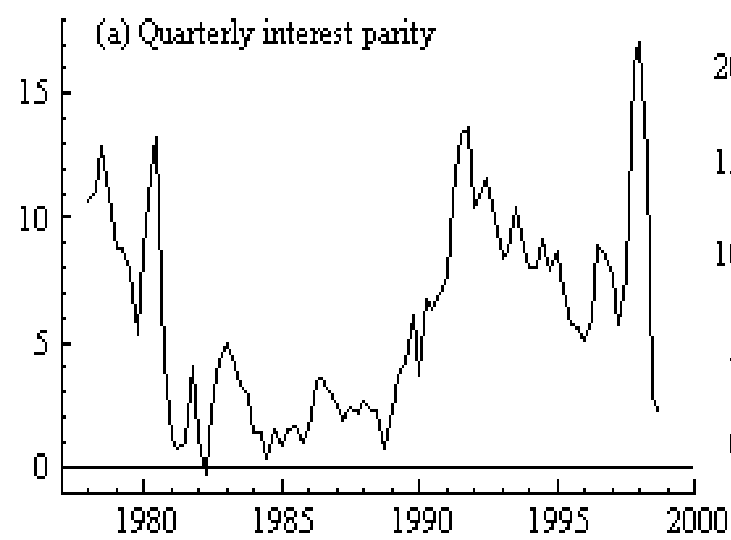

(b) Monthly interest parity
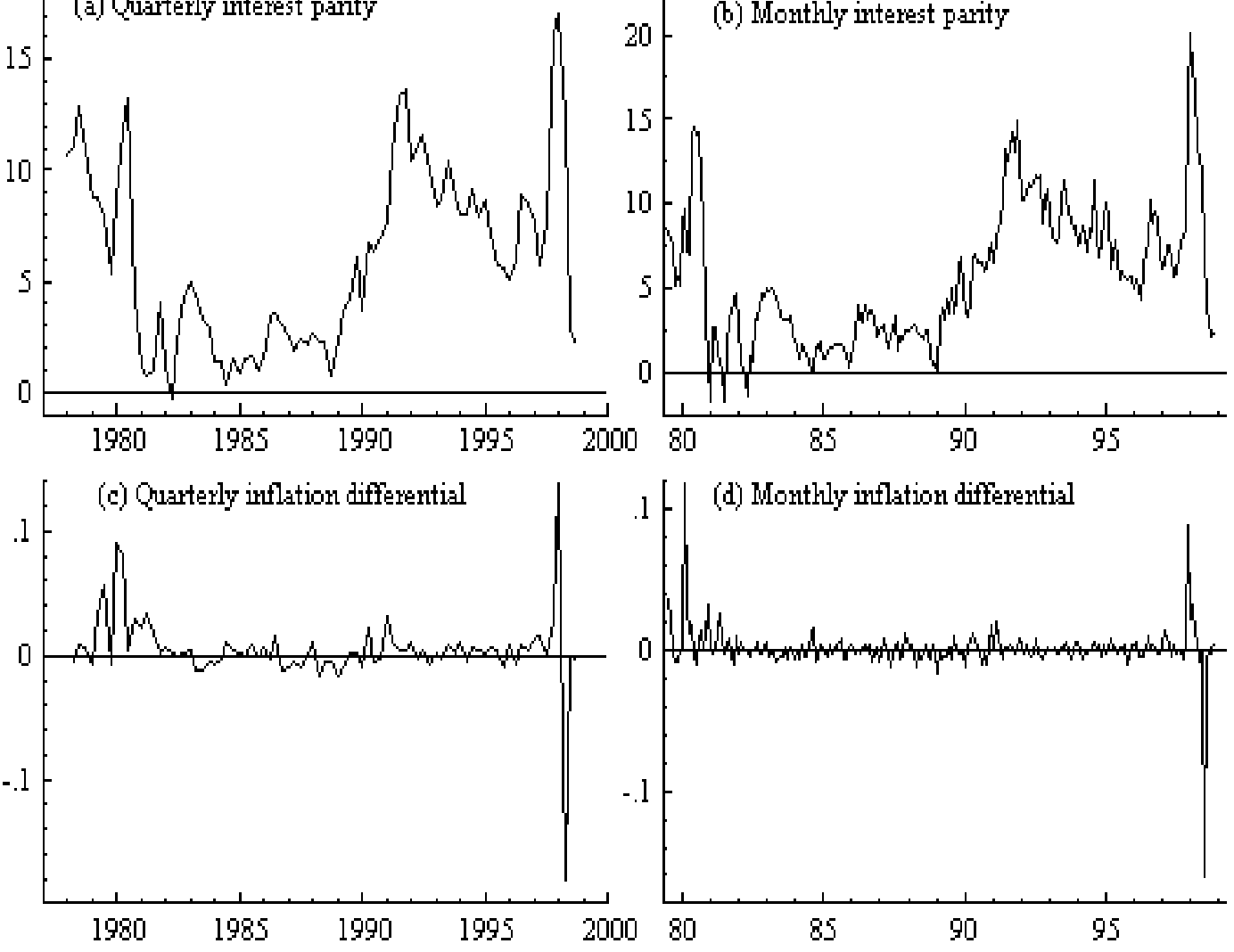
Figure 4. Institutional Variables of Excess Debt
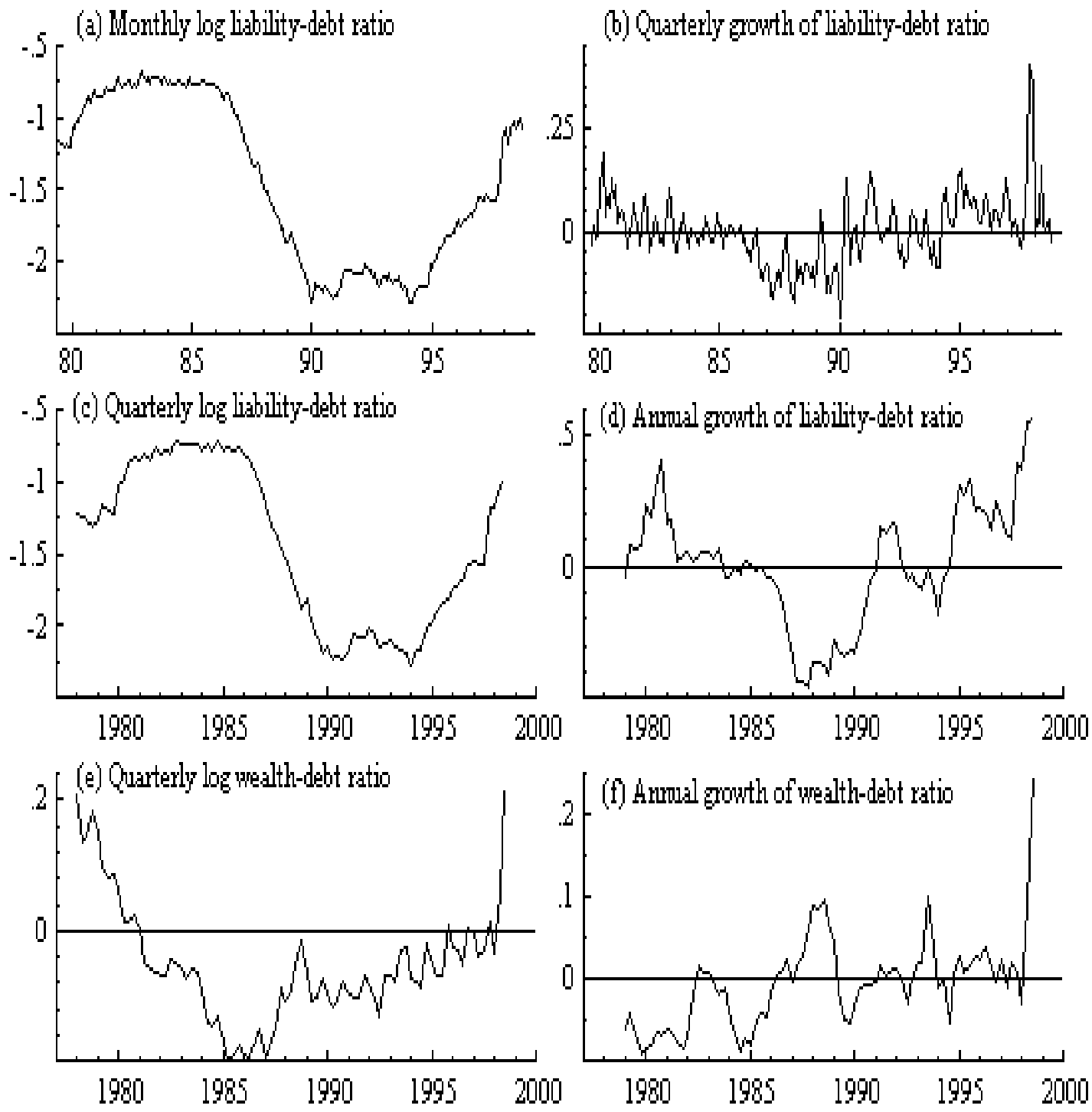

\footnotetext{
${ }^{14}$ Notice that all the series in the right-side graphs of figure 4 appear in the models (see tables 1-4) as short-run shock variables, (b) in the monthly models and (d) and (f) in the quarterly models.
} 
Figure 5. Modelled Effects of Liability-Debt Ratios
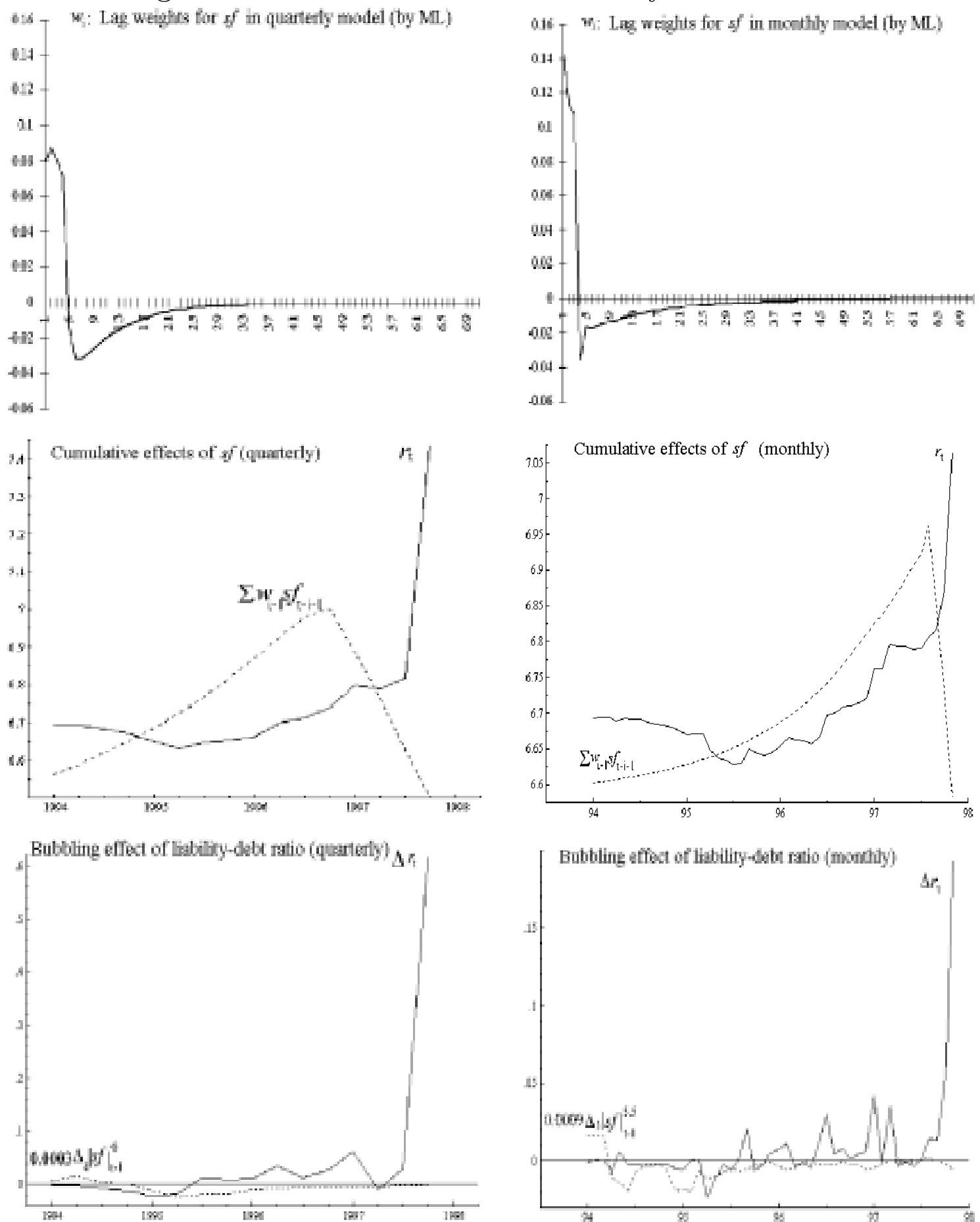
Figure 6. Model Forecasts
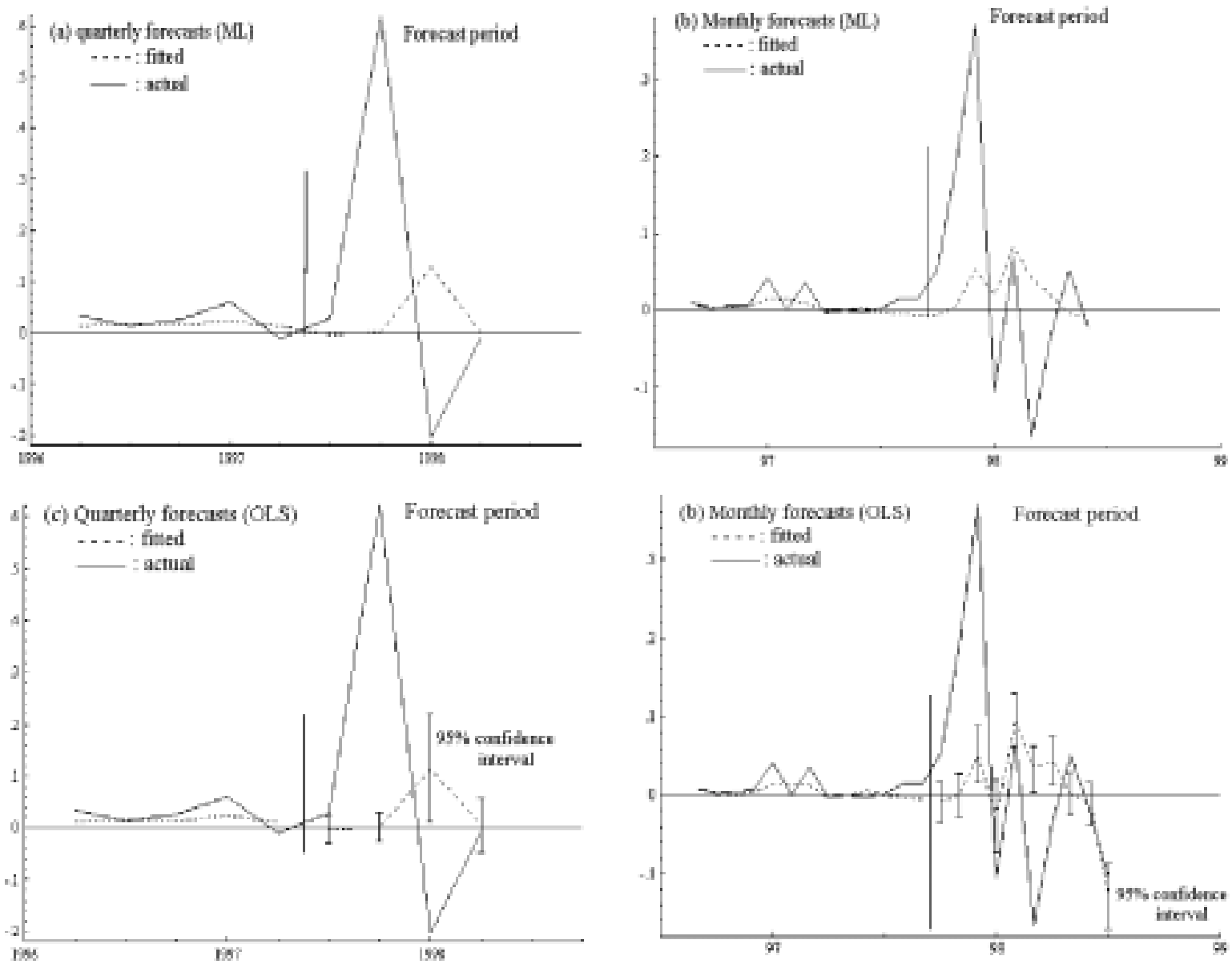
Table 1. Quarterly linear model

\begin{tabular}{|c|c|c|c|c|}
\hline Coefficient & OLS estimate & $t$-value & Partial $R^{2}$ & $\begin{array}{l}\text { Constancy test } \\
5 \% \text { critical value: } 0.47\end{array}$ \\
\hline$\theta_{0}$ & 0.0099 & 3.995 & 0.2048 & 0.09 \\
\hline$\theta_{1}$ & -0.141 & -2.608 & 0.0989 & 0.11 \\
\hline$\alpha_{1}$ & 0.2738 & 2.93 & 0.1216 & 0.24 \\
\hline$\beta_{1}$ & 0.0015 & 2.682 & 0.1039 & 0.20 \\
\hline$\gamma_{0}$ & -0.3512 & -3.462 & 0.1620 & 0.05 \\
\hline$\lambda_{11}$ & 0.0505 & 5.275 & 0.3098 & 0.05 \\
\hline$\lambda_{21}$ & -0.1627 & -4.152 & 0.2175 & 0.10 \\
\hline \multicolumn{2}{|c|}{ Sample size: $80(1)-97(3)$} & $R^{2}=0.677$ & $\widehat{\sigma}=0.0125$ & $R S S=0.00976$ \\
\hline \multicolumn{2}{|c|}{$\begin{array}{l}\qquad r_{t}= \\
\text { The fitted model: }\end{array}$} & $\begin{array}{c}\theta_{0}+\theta_{1}\left[\ln \left(\frac{P}{P}\right.\right. \\
+\alpha_{1} \Delta r_{t-1} \\
+\lambda_{11} \Delta_{4} s f_{t}\end{array}$ & $\begin{array}{l})_{t-1}-0.004 \\
-\beta_{1} \Delta_{2} I d_{t-1} \\
1+\lambda_{21} \Delta_{4} s l_{t}\end{array}$ & $\begin{array}{l}\left.d_{t-2}\right] \\
\gamma_{0} \Delta_{2} \ln \left(\frac{P_{h}}{P_{f}}\right)_{t}\end{array}$ \\
\hline \multicolumn{5}{|c|}{ Diagnostic tests } \\
\hline \multicolumn{2}{|c|}{ Alternative hypotheses } & \multicolumn{2}{|c|}{ Test statistics } & $p$-value \\
\hline \multicolumn{2}{|c|}{ residual autocorrelation } & \multicolumn{2}{|c|}{$F(3,60)=1.6468$} & 0.188 \\
\hline \multicolumn{2}{|c|}{ residual $\mathrm{ARCH}$} & \multicolumn{2}{|c|}{$F(3,57)=3.1049$} & 0.034 \\
\hline \multicolumn{2}{|c|}{ residual heteroscedasticity } & \multicolumn{2}{|c|}{$F(12,50)=1.3404$} & 0.227 \\
\hline \multicolumn{2}{|c|}{ residual normality } & \multicolumn{2}{|c|}{$\chi^{2}(2)=5.4791$} & 0.065 \\
\hline \multicolumn{2}{|c|}{ RESET } & \multicolumn{2}{|c|}{$F(1,62)=0.0024$} & 0.961 \\
\hline
\end{tabular}

\footnotetext{
${ }^{14}$ In table 1, the constancy test is a parameter instability test due to Hansen (1992); RSS stands for residual sum of squares; RESET stands for Ramsey regression error specification test.
} 
Table 2. Monthly linear model

$\left.\begin{array}{|c|c|c|c|c|}\hline \text { Coefficient } & \text { OLS estimate } & t \text {-value } & \text { Partial } R^{2} & \begin{array}{c}\text { Constancy test } \\ 5 \% \text { critical value: } 0.47\end{array} \\ \hline \theta_{0} & 0.0068 & 3.102 & 0.0448 & 0.12 \\ \hline \theta_{1} & -0.0371 & -2.302 & 0.0252 & 0.15 \\ \hline \alpha_{1} & -0.1185 & -2.195 & 0.0230 & 0.06 \\ \hline \gamma_{0} & 0.3712 & 2.595 & 0.0318 & 0.23 \\ \hline \lambda_{11} & 0.0495 & 3.784 & 0.0653 & 0.37 \\ \hline \text { Sample size: } 80(3)-97(9) & R^{2}=0.146 & \widehat{\sigma}=0.0127 & R S S=0.0033 \\ \hline \text { The fitted model: } \widehat{\Delta r_{t}}= & \theta_{0}+\theta_{1}\left[\ln \left(\frac{P_{h}}{P_{f}}\right)_{t-1}-0.01 I d_{t-2}-0.089 s f_{t-1}\right.\end{array}\right]$


Table 3. Quarterly nonlinear model

\begin{tabular}{|c|c|c|c|c|}
\hline Coefficient & $\begin{array}{c}\text { Estimate } \\
\left(\begin{array}{l}M L \\
O L S\end{array}\right)\end{array}$ & $\begin{array}{c}t \text {-value } \\
\left(\begin{array}{c}M L \\
O L S\end{array}\right) \\
\end{array}$ & $\underset{\substack{M L \\
O L S}}{\operatorname{Partial}} R^{2}$ & $\begin{array}{l}\text { Constancy test } \\
5 \% \text { critical value: } 0.47\end{array}$ \\
\hline$\theta_{0}$ & $\begin{array}{l}0.0100 \\
0.0191\end{array}$ & $\begin{array}{l}5.087 \\
4.250\end{array}$ & $\begin{array}{c}\prime \\
0.2258 \\
0\end{array}$ & $\begin{array}{l}1 \\
0.04 \\
\end{array}$ \\
\hline$\theta_{1}$ & $\begin{array}{l}-0.0932 \\
-0.1058\end{array}$ & $\begin{array}{l}-1.960 \\
-1.966\end{array}$ & $\frac{1}{0.0596}$ & 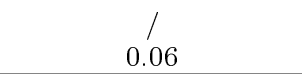 \\
\hline$\alpha_{1}$ & $\begin{array}{l}0.2160 \\
0.1954 \\
\end{array}$ & $\begin{array}{l}2.212 \\
2.055 \\
\end{array}$ & $\begin{array}{ll} \\
0.0647\end{array}$ & 0.14 \\
\hline$\beta_{1}$ & $\begin{array}{l}0.0017 \\
0.0017\end{array}$ & $\begin{array}{l}3.600 \\
3.044 \\
\end{array}$ & $\frac{1}{1}$ & $1 / 18$ \\
\hline$\gamma_{0}$ & $\begin{array}{l}-0.295 \\
-0.302 \\
\end{array}$ & $\begin{array}{l}-3.301 \\
-3.034 \\
\end{array}$ & $\frac{1}{1}$ & 0.02 \\
\hline$\lambda_{11}$ & $\begin{array}{l}0.0774 \\
0.0780 \\
\end{array}$ & $\begin{array}{l}5.458 \\
5.430 \\
\end{array}$ & $\begin{array}{ll}\prime \\
0.3259 \\
\end{array}$ & 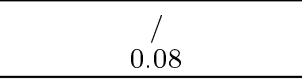 \\
\hline$\lambda_{12}$ & $\begin{array}{l}-0.119 \\
-0.129 \\
\end{array}$ & $\begin{array}{l}-3.515 \\
-3.207 \\
\end{array}$ & 0.1443 & 0.10 \\
\hline$\rho_{1}$ & $\begin{array}{l}0.0003 \\
0.0002 \\
\end{array}$ & $\begin{array}{l}3.283 \\
2.490 \\
\end{array}$ & $\begin{array}{c} \\
0.0923 \\
\end{array}$ & 0.04 \\
\hline$\tau$ & $\begin{array}{l}6.0199 \\
=6\end{array}$ & $\begin{array}{c}18.813 \\
/\end{array}$ & 1 & 1 \\
\hline$\omega_{1}$ & $\frac{0.4172}{/}$ & $\begin{array}{c}2.069 \\
/\end{array}$ & 1 & 1 \\
\hline$\Delta r_{t}=\theta$ & $\begin{array}{l}0+\theta_{1}\left[\ln \left(\frac{P_{h}}{P_{f}}\right.\right. \\
+\alpha_{1} \Delta r_{t-1}+ \\
+\lambda_{11} \Delta_{4} s f_{t-}\end{array}$ & $\begin{array}{l}t-1-0 \\
\beta_{1} \Delta_{2} I d \\
+\lambda_{21} \Delta\end{array}$ & $\begin{array}{l}\left.04 I d_{t-2}\right] \\
-1+\gamma_{0} \Delta_{2} \ln \\
s l_{t-1}+\rho_{1} \Delta_{4}\end{array}$ & $\begin{array}{l}\left(\frac{P_{h}}{P_{f}}\right)_{t} \\
\left(\left|s f_{t-1}\right|^{\iota}\right)+\nu_{t}\end{array}$ \\
\hline \multicolumn{5}{|c|}{$\sigma_{\nu_{t}}^{2}=0.0001+\omega_{1} \nu_{t-1}^{2}$} \\
\hline \multicolumn{5}{|c|}{ Sample period: 80(1)-97(2) } \\
\hline
\end{tabular}

\footnotetext{
${ }^{14}$ In tables 3 and 4 , the value of $\omega_{0}$ is fixed at the estimated residual variance of the linear models (see tables 1 and 2). The estimation would run into singularity problem if this coefficient is not fixed.
} 
Table 4. Monthly nonlinear model

\begin{tabular}{|c|c|c|c|c|}
\hline Coefficient & $\begin{array}{c}\text { Estimate } \\
\left(\begin{array}{c}M L \\
O L S\end{array}\right)\end{array}$ & $\begin{array}{c}t \text {-value } \\
\left(\begin{array}{c}M L \\
O L S\end{array}\right)\end{array}$ & $\underset{\left(\begin{array}{c}M L \\
O L S\end{array}\right)}{\operatorname{Partial}} R^{2}$ & $\begin{array}{c}\text { Constancy test } \\
5 \% \text { critical value: } 0.47\end{array}$ \\
\hline$\theta_{0}$ & $\begin{array}{l}0.0145 \\
0.0063 \\
\end{array}$ & $\begin{array}{l}7.263 \\
2.962 \\
\end{array}$ & $\begin{array}{c}1 \\
0.0406 \\
\end{array}$ & $\frac{1}{1}$ \\
\hline$\theta_{1}$ & $\begin{array}{l}-0.0860 \\
-0.0302 \\
\end{array}$ & $\begin{array}{l}-5.952 \\
-1.947 \\
\end{array}$ & $\frac{1}{1}$ & $1 / 1$ \\
\hline$\alpha_{1}$ & $\begin{array}{l}-0.118 \\
-0.240 \\
\end{array}$ & $\begin{array}{l}-2.748 \\
-4.445 \\
\end{array}$ & ${ }_{0.0871}^{\prime}$ & $\begin{array}{c}/ \\
0.09 \\
\end{array}$ \\
\hline$\gamma_{0}$ & $\begin{array}{l}0.6252 \\
0.9344 \\
\end{array}$ & $\begin{array}{l}4.819 \\
9.629 \\
\end{array}$ & $\begin{array}{c}\prime \\
0.3094 \\
\end{array}$ & ${ }^{\prime} / 11$ \\
\hline$\lambda_{11}$ & $\begin{array}{l}0.1352 \\
0.1163 \\
\end{array}$ & $\begin{array}{l}8.797 \\
5.438 \\
\end{array}$ & 0.1250 & $1 /$ \\
\hline$\rho_{1}$ & $\begin{array}{l}0.0009 \\
0.0007\end{array}$ & $\begin{array}{l}6.141 \\
4.325 \\
\end{array}$ & ${ }_{0.0829}^{\prime}$ & ${ }^{\prime}$ \\
\hline$\tau$ & $\begin{array}{l}5.4492 \\
=5.5\end{array}$ & $\begin{array}{c}31.647 \\
/\end{array}$ & / & / \\
\hline$\omega_{1}$ & $\begin{array}{c}0.5245 \\
/\end{array}$ & $\begin{array}{c}3.794 \\
/\end{array}$ & I & / \\
\hline \multicolumn{5}{|c|}{$\begin{array}{c}\Delta r_{t}=\theta_{0}+\theta_{1}\left[\ln \left(\frac{P_{h}}{P_{f}}\right)_{t-1}-0.01 I d_{t-2}-0.089 s f_{t-1}\right] \\
+\alpha_{1} \Delta r_{t}+\gamma_{0} \Delta \ln \left(\frac{P_{h}}{h}\right)_{t}\end{array}$} \\
\hline \multirow[t]{2}{*}{$\sigma_{\nu_{t}}^{2}=$} & \multicolumn{4}{|c|}{$0.0001+\omega_{1} \nu_{t-1}^{2}$} \\
\hline & \multicolumn{4}{|c|}{ Sample period:80(1)-97(10) } \\
\hline
\end{tabular}


Table 5. Unit root tests

\begin{tabular}{|c|c|c|c|c|}
\hline & $\begin{array}{l}\text { Qua } \\
\text { sub-sample } \\
80(1)-97(2)\end{array}$ & $\begin{array}{l}\text { rterly } \\
\text { full-sample } \\
80(1)-98(2)\end{array}$ & $\begin{array}{l}\text { Mor } \\
\text { sub-sample } \\
80(1)-97(8)\end{array}$ & $\begin{array}{l}\text { thly } \\
\text { full sample } \\
80(1)-98(6)\end{array}$ \\
\hline variables & $\begin{array}{l}\text { DF test } \\
{\left[\begin{array}{l}5 \% \text { c.v.: } \\
-2.904\end{array}\right]}\end{array}$ & $\begin{array}{l}\operatorname{ADF}(3) \text { test } \\
{\left[\begin{array}{l}5 \% \text { c.v.: } \\
-2.906\end{array}\right]}\end{array}$ & $\begin{array}{l}\text { DF test } \\
{\left[\begin{array}{c}5 \% \text { c.v.: } \\
-2.875\end{array}\right]}\end{array}$ & $\begin{array}{l}\operatorname{ADF}(6) \text { test } \\
{\left[\begin{array}{l}5 \% \text { c.v.: } \\
-2.876\end{array}\right]}\end{array}$ \\
\hline $\begin{array}{l}\log \text { nominal rate } \\
r_{t}\end{array}$ & $-2.893 /-1.07$ & $-1.943 /-0.2777$ & $-4.827 /-0.9723$ & $-1.914 /-1.34$ \\
\hline $\begin{array}{l}\log \text { real rate } \\
r_{t}-\ln \left(\frac{P_{h}}{P_{f}}\right)_{t}\end{array}$ & $-1.33 /-2.355$ & $-3.139 /-0.215$ & $-2.138 /-1.774$ & $-2.617 /-1.382$ \\
\hline $\begin{array}{l}\text { nominal returns } \\
\qquad \Delta r_{t}\end{array}$ & $-7.525 /-10.77$ & $-2.952 /-0.786$ & $-14.04 /-13.68$ & $-3.621 /-5.252$ \\
\hline $\begin{array}{l}\text { real returns } \\
\Delta\left[r-\ln \left(\frac{P_{h}}{P_{f}}\right)\right]_{t}\end{array}$ & $-9.772 /-13.07$ & $-4.557 /-2.288$ & $-13.35 /-13.49$ & $-4.69 /-5.625$ \\
\hline $\ln \left(\frac{P_{h}}{P_{f}}\right)_{t}$ & $-5.119 /-2.075$ & $-6.199 /-2.448$ & $-8.345 /-2.995$ & $-6.56 /-3.0$ \\
\hline
\end{tabular}

Table 6. Correlation coefficients

\begin{tabular}{lccc}
\hline \hline Quarterly & $\Delta_{2} \ln \left(\frac{P_{h}}{P_{f}}\right)_{t}$ & $\Delta_{2} I d_{t}$ & {$\left[\ln \left(\frac{P_{h}}{P_{f}}\right)_{t}-0.004 I d_{t-1}\right]$} \\
\hline$\Delta_{4} s l_{t}$ & -0.31 & 0.058 & 0.39 \\
$\Delta_{4} s f_{t}$ & -0.54 & 0.041 & -0.12 \\
change in & $-84 \%$ & $-37 \%$ & $-97 \%$ \\
Partial $R^{2}$ & & & $\left(\ln \frac{P_{h}}{P_{f}}-0.01 I d_{t-1}-0.089 s f\right)_{t}$ \\
\hline Monthly & $\Delta \ln \left(\frac{P_{h}}{P_{f}}\right)_{t}$ & & -0.078 \\
$\Delta_{3} s f_{t}$ & 0.105 & & $-60 \%$ \\
change in & $+43 \%$ & & \\
Partial $R^{2}$ & & & \\
\hline \hline
\end{tabular}

\footnotetext{
${ }^{14}$ In table $5, \mathrm{DF}$ stands for Dickey-Fuller test and $\operatorname{ADF}(n)$ stands for augmented DF test with $n$ lags; c.v. stands for critical value.
} 